\title{
Możliwości spajania węglików spiekanych ze stalą wiązką lasera
}

\section{Possibilities of laser-beam joining hardmetals to steel}

\section{Streszczenie}

Połączenia spajane węglików spiekanych ze stalą powszechnie występują w produkcji narzędzi, stosowanych głównie w obróbce skrawaniem i w przemyśle wydobywczym. W artykule przedstawiono możliwości łączenia węglików spiekanych H10S i G10 ze stalą C45 za pomocą promienia lasera. Są to pierwsze, innowacyjne próby przeprowadzone w kraju. Połączenia pomiędzy węglikami spiekanymi i stalą wykonano jako bezpośrednie oraz przy zastosowaniu przekładek między łączonymi materiałami, wykonanych z miedzi, lutu 3-warstwowego Ag49/Cu oraz niklu. Próby spajania wykonano w Centrum Techniki Laserowej w Instytucie Spawalnictwa w Gliwicach. W tym celu zastosowano laser dyskowy $(\lambda=1030 \mathrm{~nm})$ TruDisk 12002 o mocy $12 \mathrm{~kW}$, firmy Triumpf. Wiązka lasera ogniskowano najczęściej na powierzchni stali, aby nie doprowadzić do bezpośredniego oddziaływania lasera na strukturę węglików spiekanych. Ocenę złączy węglików spiekanych ze stalą C45 przeprowadzono na podstawie badań metalograficznych, analiz EDX i pomiarów mikrotwardości.

\section{Wstęp}

Węgliki spiekane zaliczane są do materiałów o warunkowej zdolności do spajania $z$ powodu specyficznych właściwości powierzchniowych oraz bardzo odmiennych, w porównaniu ze stalą, właściwości fizycznych i mechanicznych. Podstawowe trudności, występujące podczas zwilżania lutem powierzchni węglików spiekanych, wynikają z obecności:

- trudno zwilżalnych tlenków wolframu,

- trudno zwilżalnych węglików wolframu WC, a szczególnie węglików tytanu $\mathrm{TiC}$, tantalu $\mathrm{TaC}$ i niobu $\mathrm{NbC}$

Dr hab. inż. Zbigniew Mirski, prof. nadzw. PWr, dr hab. inż. Kazimierz Granat, prof. nadzw. PWr - Politechnika Wrocławska, dr inż. Sebastian Stano - Instytut Spawalnictwa, Gliwice.

\section{Abstract}

Welded joints of hardmetals with steel are commonly present in manufacture of tools, mainly those used in the machining and in the mining industry. The paper presents possibilities of joining hardmetals $\mathrm{H} 10 \mathrm{~S}$ and $\mathrm{G} 10$ with steel C45 using laser radiation. These are first, innovative experiments carried-out in Poland. Joints between hardmetals and steel were made both directly and using spacers of copper, 3-layer filler Ag49/Cu and nickel between the materials to be joined. The trials were carried-out at Laser Technology Centre of the Polish Centre for WeIding Technology in Gliwice. Applied was a disk laser TruDisk $12002(\lambda=1030 \mathrm{~nm}$, output power $12 \mathrm{~kW})$ made by Triumpf. The laser beam was basically focused on steel surface to avoid direct action of laser beam on hardmetal structure. Joints of hardmetals with C45 steel were evaluated on the grounds of metallographic observations, EDX analyses and microhardness measurements.

Węgliki spiekane charakteryzuja się w porównaniu ze stalami do ulepszania cieplnego [1-5]:

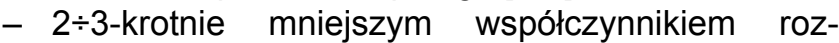
szerzalności liniowej $\left(a_{w}=4,5 \div 7 \cdot 10^{-6} \quad 1 / \mathrm{K}\right.$, $\left.a_{s}=11 \div 14 \cdot 10^{-6} 1 / K\right)$, zależnie od temperatury,

- większą przewodnością cieplną $\left(\alpha_{w}=38 \div 67 \mathrm{~W} / \mathrm{m} \cdot \mathrm{K}\right.$, $\left.\alpha_{\mathrm{s}}=26 \div 60 \mathrm{~W} / \mathrm{m} \cdot \mathrm{K}\right)$ [5],

- 3 - krotnie większym modułem sprężystości wzdłużnej,

- bardzo małą zdolnością do odkształceń, na poziomie $0,1 \div 0,3 \%$ w temperaturze otoczenia, w związku z czym wykazują dużą skłonność do kruchego pękania [4],

- trwalszymi warstwami tlenkowymi na powierzchni spajania.

Spajanie węglików spiekanych ze stalą w produkcji narzędzi, stosowanych szczególnie w obróbce skrawaniem i w przemyśle wydobywczym, wykonuje się przede wszystkim za techniką lutowania twardego (rys. 1). 

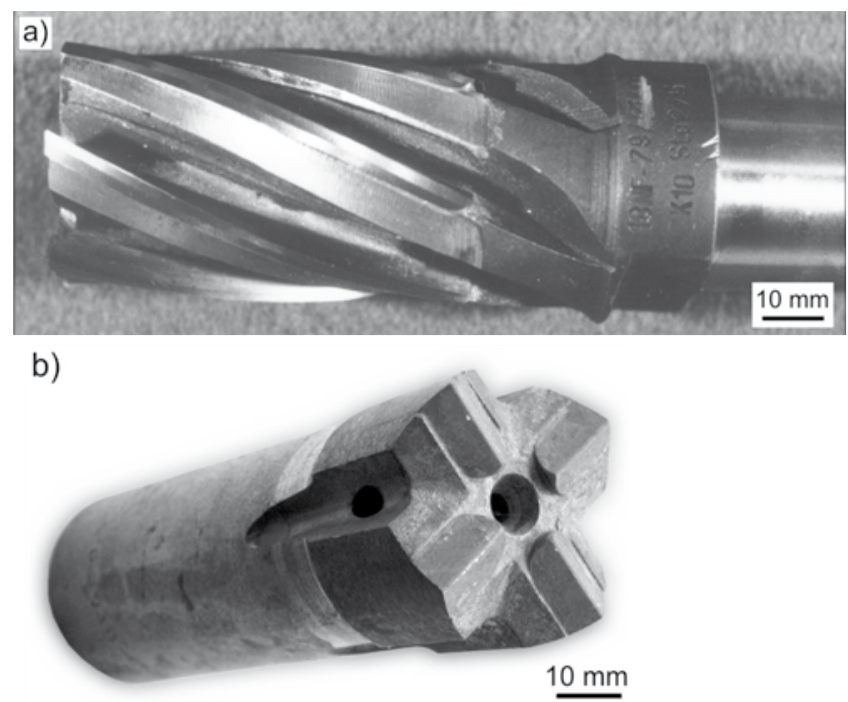

Rys. 1. Połączenia węglików spiekanych ze stalą wykonane techniką lutowania twardego: a) frez walcowo-czołowy, b) koronka 4-krzyżowa [1]

Fig. 1. Brazed joints of hardmetals with steel: a) end milling cutter, b) 4-cross bit [1]
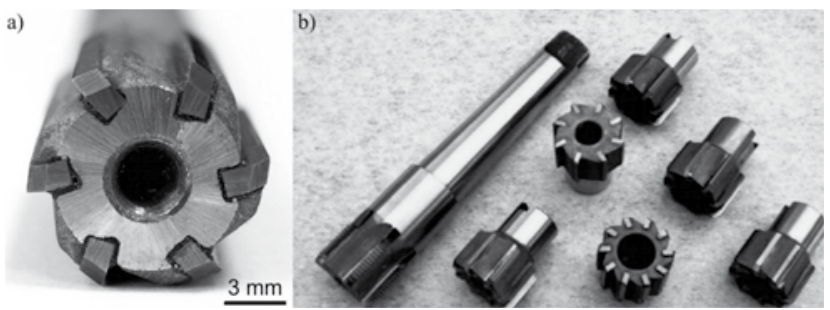

Rys. 2. Płytki węglikowe w korpusach rozwiertaków umocowane metodą klejenia (a) [1] i (b) $[7,8]$

Fig. 2. Adhesive joints of hardmetal plates in reamer bodies (a) [1] and (b) $[7,8]$

W przypadku narzędzi o mniejszych wymaganiach eksploatacyjnych coraz częściej konstruktorzy i technolodzy wdrażają technikę klejenia (rys. 2) [1, 6].

Głównymi ograniczeniami w stosowaniu klejenia jest stosunkowo niewielka wytrzymałość mechaniczna połączeń klejowych (wytrzymałość na ścinanie nie przekracza $50 \mathrm{MPa}$ ) oraz ograniczona odporność na działanie wysokiej temperatury, szczególnie powyżej $150^{\circ} \mathrm{C}$.

Metody spawania charakteryzują się najwyższą temperaturą procesu w porównaniu $z$ innymi metodami spajania, zwłaszcza ze względu na konieczność nadtopienia łączonych materiałów. Nadtopienie stali nie stwarza większych problemów, natomiast stopienie węglików spiekanych prowadzi do ich zniszczenia. Spawanie węglików spiekanych powoduje nadtopienie płytek po przekroczeniu temperatury topnienia osnowy kobaltowej $\left(1350^{\circ} \mathrm{C}\right)$ i temperatury rozpadu węglików wolframu WC, wynoszącej $2600^{\circ} \mathrm{C}$ [5]. Powoduje to tworzenie twardych i kruchych faz międzymetalicznych na granicy połączenia. $Z$ kolei skurcz spoiny podczas chłodzenia połączenia prowadzi do znacznych lokalnych naprężeń cieplnych i pęknięć. $Z$ tego bierze się powszechna opinia o braku możliwości spawania węglików spiekanych. Mimo to znane są opatentowane przykłady ręcznego spawania łukiem elektrycznym węglików spiekanych ze stalą przy użyciu elektrody otulonej lub półautomatycznie metodą MIG [9:11]. Spośród metod spawalniczych korzystniejsze jest użycie skoncentrowanych źródeł energii, takich jak wiązka elektronów lub promień lasera, umożliwiających zminimalizowanie strefy wpływu ciepła oraz zmniejszenie naprężeń cieplnych w połączeniu spawanym. W badaniach zastosowano promień lasera.

\section{Materiały do połączeń}

Do spajania wybrano następujące materiały podstawowe:

- stal C45 po ulepszaniu cieplnym,

- węgliki spiekane H10S (91,5\% WC, 4\% (Ti+Ta$\mathrm{c}+\mathrm{NbC}), 4,5 \%$ Co wg PN-H-89500:1988) pokryte warstwą kobaltu grubości $5 \mu \mathrm{m}$,

- węgliki spiekane H10S (94\% WC, 6\% Co). Jako materiały dodatkowe, zastosowano następujące przekładki:

- miedź w postaci taśmy grubości 0,1 mm;

- lut przekładkowy Ag49/Cu, o temperaturze topnienia $670 \div 690^{\circ} \mathrm{C}$, w postaci taśmy o łącznej grubości $0,4 \mathrm{~mm}$ (warstwa Cu o grubości 0,2 $\mathrm{mm}$ i platerowana warstwa lutu srebrnego $\mathrm{Ag} 49$ po obu stronach warstwy $\mathrm{Cu}$ o grubości po 0,1 mm) (rys. 3). Spoiwo to jest często stosowane w lutowaniu twardym węglików spiekanych ze stalą ze względu na możliwość kompensacji naprężeń własnych przez środkową warstwę miedzi. Jego zadaniem jest niedodopuszczenie do pęknięć w węglikach spiekanych, zwłaszcza w narzędziach wieloostrzowych o skomplikowanej konstrukcji;

- nikiel (temperatura topnienia $1455^{\circ} \mathrm{C}$ ) w postaci taśmy grubości 0,1 mm.

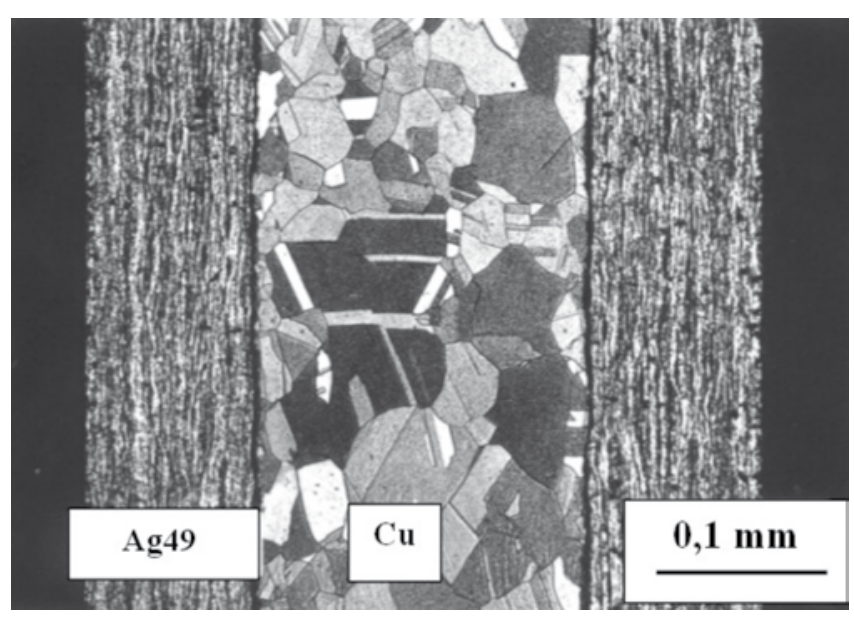

Rys. 3. Przekrój poprzeczny srebrnego lutu przekładkowego Ag49/Cu, o grubości taśmy 0,4 mm [1]

Fig. 3. Cross-section of composite filler $\mathrm{Ag} 49 / \mathrm{Cu}$; tape $0.4 \mathrm{~mm}$ thick [1]

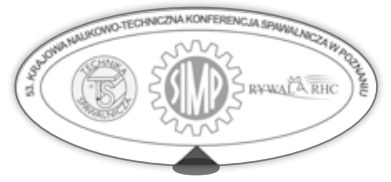


Prostopadłościenne próbki ze stali i z węglików spiekanych, o wymiarach $3,5 \times 4,5 \times 8,0 \mathrm{~mm}$ (grubość $\mathrm{x}$ szerokość x długość), przygotowano, tak, aby zapewnić styk elementów na całej powierzchni, bez wystąpienia szczelin. Powierzchnie elementów stalowych do łączenia były frezowane, a niepokrywanych płytek węglikowych H10S szlifowane. Wszystkie materiały odtłuszczano w acetonie. Łączone materiały były ustalane w przyrządzie i mocowane w małym imadełku.

\section{Stanowisko laserowe i próby spajania}

Próby połączenia węglików spiekanych ze stalą przeprowadzono w Centrum Technik Laserowych w Instytucie Spawalnictwa w Gliwicach (rys. 4). Próby spajania wykonano laserem dyskowym $(\lambda=1030 \mathrm{~nm})$ TruDisk 12002 o mocy 12 kW, firmy Triumpf.

Próby spajania przeprowadzono, łącząc bezpośrednio oba materiały, jak również przy zastosowaniu przekładek. Pierwsze próby wykonano przy ustawieniu promienia lasera (ogniskowa $300 \mathrm{~mm}$, średnica ogniska 0,45 mm, położenie ogniska wiązki laserowej - na materiale $f=0$ ) na powierzchni stali w odległości 0,8 $\mathrm{mm}$ od linii styku łączonych elementów. Dotyczyło to połączeń kobaltowanych węglików spiekanych H10S ze stalą C45 bezpośrednio i przy użyciu przekładki miedzianej. Połączenia te wykonano przy mocy lasera $2 \mathrm{~kW}$, prędkości 4,5 $\mathrm{m} / \mathrm{min}$ i nadmuchu argonu $18 \mathrm{dm}^{3} / \mathrm{h}$. Głębokość wnikania promienia lasera wynosiła $1 \mathrm{~mm}$. Kolejne próby spajania, z przekładką z lutu 3-warstwowego Ag49/Cu i przekładką niklową, wykonano przy parametrach umożliwiających uzyskanie pełnego przetopu na głębokości sięgającej 3,5 mm (pozostałe parametry bez zmian):

- moc wiązki laserowej 5,2 kW,

- prędkość spawania $6 \mathrm{~m} / \mathrm{min}$,

- średnica plamki ogniska wiązki laserowej 0,3 mm.

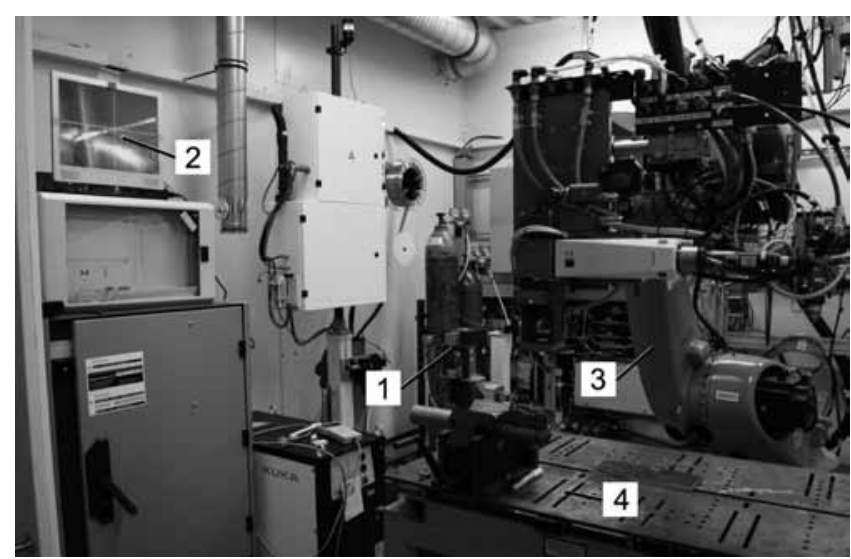

Rys. 4. Stanowisko do spawania promieniem lasera w Instytucie Spawalnictwa w Gliwicach; 1 - głowica lasera, 2 - ekran pokazujący ogniskowanie promienia lasera, 3 - ramię robota firmy Kuka, 4 - stół z oprzyrządowaniem

Fig. 4. Stand for laser-beam welding at Welding Technology Centre in Gliwice; 1 - laser head, 2 - screenshot showing laser-beam focusing, 3 - arm of the Kuka robot, 4 - table with instrumentation

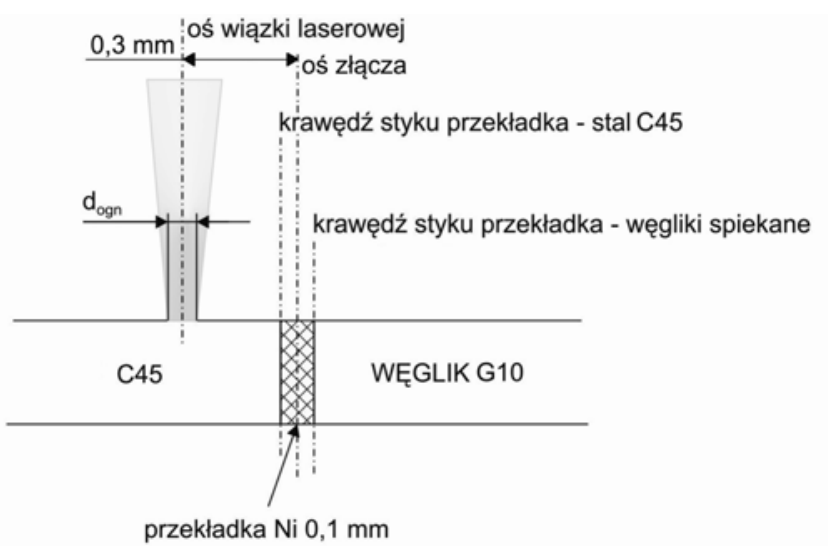

Rys. 5. Schemat usytuowania wiązki laserowej przy spajaniu węglików spiekanych G10 ze stalą C45 z zastosowaniem przekładki niklowej

Fig. 5. Outline of laser-beam location for joining hardmetal G10 with steel $\mathrm{C} 45$ with use of a nickel spacer

Połączenie wykonano, umieszczająć promień lasera na styku przekładki ze stalą.

Schemat połączenia płytki z węglików spiekanych H10S ze stalą C45 przy użyciu przekładki niklowej pokazano na rysunku 5. Oś wiązki laserowej była przesunięta w kierunku stali o $0,3 \mathrm{~mm}$ od osi złącza.

\section{Badania metalograficzne}

Próbki do zgładów metalograficznych inkludowano w żywicy epoksydowej, następnie szlifowano na tarczach diamentowych odpowiadających papierom ściernym SiC 220 i 600 i papierach ściernych SiC 1200, 2400 i 4000, po czym polerowano tlenkiem glinu.

Przygotowane zgłady poddano obserwacji na mikroskopie świetlnym Olympus CA 25, sprzężonym z aparatem cyfrowym Camedia C 3030 i systemem archiwizacji obrazu. Początkowo zgłady obserwowano w stanie nietrawionym, a następnie po trawieniu chemicznym Nitalem. Oceny połączeń dokonano również za pomocą analizy EDX (metoda dyspersji energii wzbudzonego promieniowania rentgenowskiego), elektronowego mikroskopu analizującego typu SEM 515 firmy Philips i mikroanalizatora rentgenowskiego 9800 firmy EDAX (USA) oraz pomiarów mikrotwardości HV0,1.

Wszystkie cztery rodzaje połączeń, przekazane do badań metalograficznych, nie wykazały pęknięć.

$\mathrm{Na}$ rysunku 6 pokazano złącze spawane H10SC45, wykonane bez udziału materiału dodatkowego. $\mathrm{Na}$ złączu widoczna jest spoina, która powstała ze stopienia stali C45 (rys. 6a). Jej twardość wynosi 518 $\div 573$ HV0,1 i w tej strefie nie zaobserwowano pęknięć. Na granicy połączenia materiałów występują miejscowe nieciągłości. Jasna strefa wpływu ciepła w obszarze 


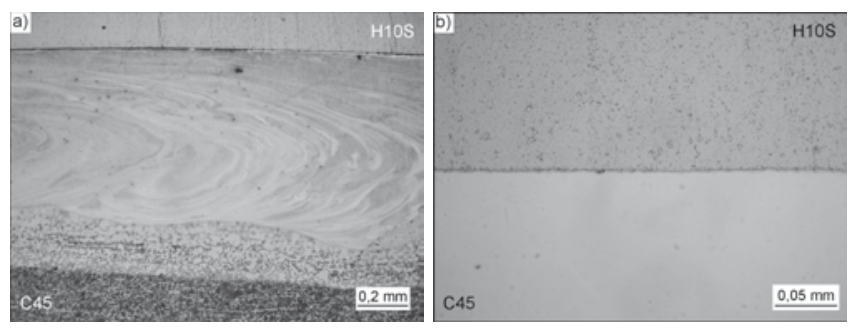

Rys. 6. Połączenie bezpośrednie węglików spiekanych $\mathrm{H} 10 \mathrm{~S}$ ze stalą C45, widok złącza z góry; trawiono chemicznie Nitalem: a), granica połączenia, b) w stanie nietrawionym

Fig. 6. Direct joint of hardmetal $\mathrm{H} 10 \mathrm{~S}$ with steel $\mathrm{C} 45$, top view; etched with Nital (a), joint boundary, unetched (b)

stali wykazuje twardość $430 \mathrm{HV} 0,1$. Jest ona stosunkowo wąska, jej szerokość wynosi $0,15 \div 0,2 \mathrm{~mm}$. Za strefą wpływu ciepła, występuje strefa materiału rodzimego o niezmienionej strukturze ferrytyczno-perlitycznej.

Większe możliwości uzyskania poprawnego połączenia stwarza zastosowanie przekładek o niższej temperaturze topnienia od łączonych materiałów. Na rysunku 7 pokazano strukturę połączenia, wykonanego przy podobnych parametrach, ale przy zastosowaniu przekładki miedzianej pomiędzy materiałami. W wyniku oddziaływania promienia lasera, skierowanego na stal, nastąpiło stopienie zarówno stali C45, jak i miedzi, spełniającej funkcję spoiwa lutowniczego. Na granicy połączenia z węglikami spiekanym widoczna jest wąska strefa reakcyjna. $W$ wyniku oddziaływania promienia lasera powstała strefa wymieszania stali z miedzią. Jej twardość zawiera się w granicach $536 \div 638$ HV0,1. Analiza podwójnego układu równowagi Cu-Fe pozwala zauważyć, że rozpuszczalność w stanie stałym miedzi w żelazie $\delta$ wynosi $6,5 \%$ wag., w żelazie y $8 \%$ wag., a w żelazie a $1,4 \%$ wag. [12]. W stanie ciekłym, w temperaturze $1094^{\circ} \mathrm{C}$, miedź rozpuszcza $45 \%$ wag. żelaza. Rozpuszczalność ta spada wyraźnie z obniżeniem temperatury i wynosi $0,4 \% \mathrm{Fe}$ w temperaturze $750^{\circ} \mathrm{C}$, a w temperaturze $650^{\circ} \mathrm{C}$ jedynie $0,2 \%$ wag. Fe. W temperaturze pokojowej, w stanie równowagi, w układzie Cu-Fe występuje roztwór stały z zawartością 0,3\% wag. Cu (faza $\alpha$ ), roztwór stały o zawartości max 0,2\% wag. Fe w Cu (faza $\varepsilon$ ) i mieszanina faz a i $\varepsilon$. Węgiel, jako składnik stali, wpływa nieznacznie na rozpuszczalność miedzi w żelazie w stanie stałym [12]. Może łatwo dojść do pęknięć na gorąco w stali w wyniku rozpuszczenia w niej znacznej zawartości miedzi.

Makrostrukturę złącza węglików spiekanych G10 ze stalą C45, przy użyciu przekładki z lutu 3-warstwowego Ag49/Cu, pokazano na rysunku 8. Dolna część złącza widoczna jest po lewej stronie.

Mikrostrukturę połączenia wykonanego z zastosowaniem przekładki z lutu 3-warstwowego Ag49/Cu przedstawiono na rysunku 9.

Przekładka 3-warstwowa Ag49/Cu, ze środkową warstwą miedzi, uległa całkowitemu przetopieniu i wymieszaniu z warstwą stali. Obszar węglików spiekanych w bezpośrednim sąsiedztwie lutu nie uległ zmianie, a analiza EDX, na powierzchni $20 \times 20 \mu \mathrm{m}$, nie wykazała obecności składników lutu i stali. Od strony węglików spiekanych warstwa lutu jest miękka, a jej twardość wynosi 100 $\div 132 \mathrm{HV0}, 1$. Strefa ta (D), blisko granicy z płytką węglikową, zawiera EDX w \% wag.: 50,28 Cu, 35,47 Ag, 2,87 Mn i 11,37 Zn. W warstwie środkowej złącza występują „wysepki” (C), stanowiące wymieszanie żelaza z miedzią (w \% wag. 94,88\% Fe, reszta $\mathrm{Cu}$ ). Od strony stali, na granicy połączenia powstały dwie strefy (A i B) o zróżnicowanej szerokości. Pierwsza strefa jest wąska, o szerokości sięgającej do ok. $40 \mu \mathrm{m}$, i o znacznej twardości wynoszącej 662 HV0,1. Jest to strefa o znacznym przechłodzeniu, bez ujawnionej struktury po trawieniu chemicznym. Następna strefa A o szerokości ok. 0,3 mm jest również twarda $(502 \div 772$ HV0,1) i stwarza możliwość wystąpienia pęknięć. W obu strefach nie stwierdzono obecności składników lutu.

Rozkład twardości w złączu z przekładką lutowniczą Ag49/Cu pokazano na rysunku 10.

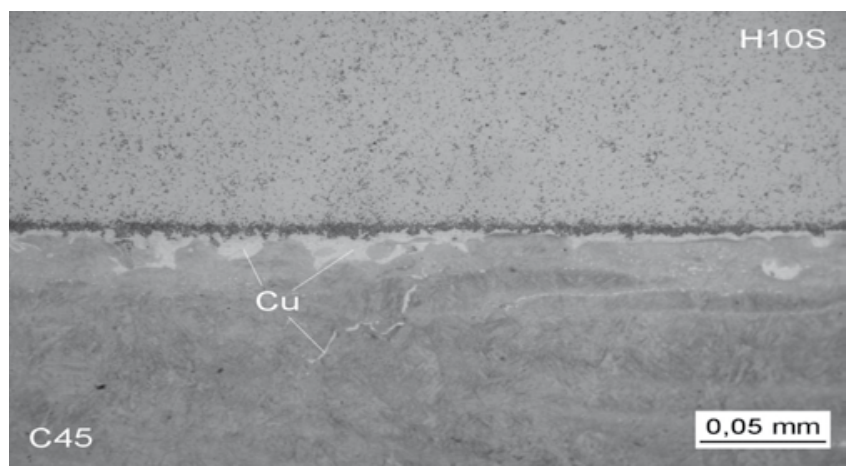

Rys. 7. Połączenie węglików spiekanych $\mathrm{H} 10 \mathrm{~S}$ ze stalą $\mathrm{C} 45$ z przekładką $\mathrm{Cu}(0,1 \mathrm{~mm})$, trawione Nitalem

Fig. 7. Joint of hardmetal H10S with steel $\mathrm{C} 45$ made with use of a copper spacer $(0.1 \mathrm{~mm})$; etched with Nital

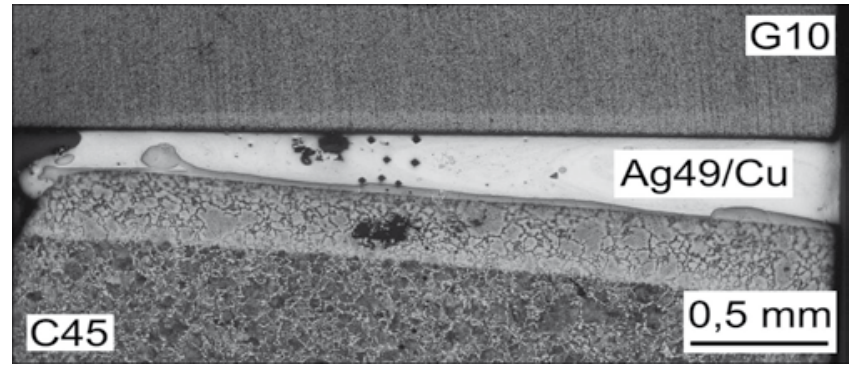

Rys. 8. Makrostruktura połączenia węglików spiekanych G10 ze stalą C45, wykonanego z przekładką Ag49/Cu

Fig. 8. Macrostructure of a joint of hardmetal G10 with steel C45 made with use of an Ag49/Cu spacer
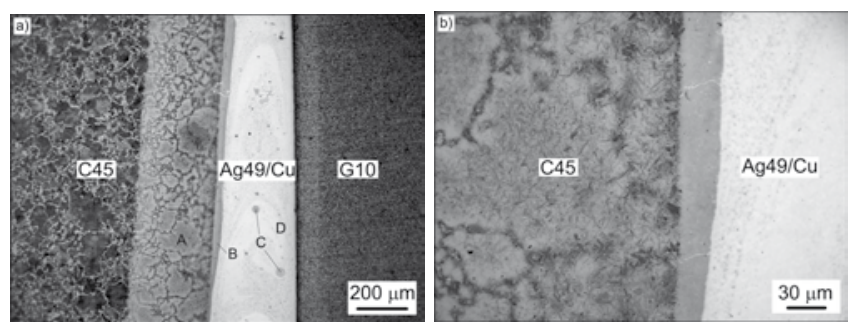

Rys. 9. Mikrostruktura połączenia węglików spiekanych G10 ze stalą C45 z przekładką Ag49/Cu (a), połączenie od strony stali (b), trawione Nitalem

Fig. 9. Microstructure of a joint of hardmetal G10 with steel C45 made with use of an Ag49/Cu spacer (a), joint on the steel side (b); etched with Nital 
Na rysunku 11 pokazano mikrostrukturę połączenia węglików spiekanych $\mathrm{G} 10$ ze stalą C45 przy użyciu przekładki niklowej.

Analizy EDX wykazały stopienie przekładki niklowej $(0,1 \mathrm{~mm})$ i jej wymieszanie ze stalą oraz wolframem. W ten sposób powstała $w$ środku połączenia warstwa o szerokości dochodzącej do $0,45 \mathrm{~mm}$. W zależności od punktu analizy, wykazuje ona obecność stopu Fe-Ni lub Fe-Ni-W. W odległości $15 \mu \mathrm{m}$ od granicy ze stalą występuje (w \% wag.) zawartość $86,28 \% \mathrm{Fe}$, reszta Ni. W odległości $0,11 \mathrm{~mm}$ od powierzchni stali pojawia się już wolfram i w tym miejscu analiza EDX wykazuje obecność $8,21 \% \mathrm{~W}, 22,11 \% \mathrm{Ni}$ i reszta Fe. W odległości $15 \mu \mathrm{m}$ od granicy z powierzchnią węglików spiekanych zawartość wolframu rośnie do wartości $23,35 \%$, zawartość niklu wynosi $17,38 \%$, reszta to żelazo.

Mimo obecności wolframu przetopiona warstwa jest miękka, jej twardość w stopiwie wynosi $209 \div 244 \mathrm{HVO}, 1$. Pozwala to na kompensacje naprężeń własnych w łączeniu materiałów o zróżnicowanej rozszerzalności cieplnej. W obszarze stali na

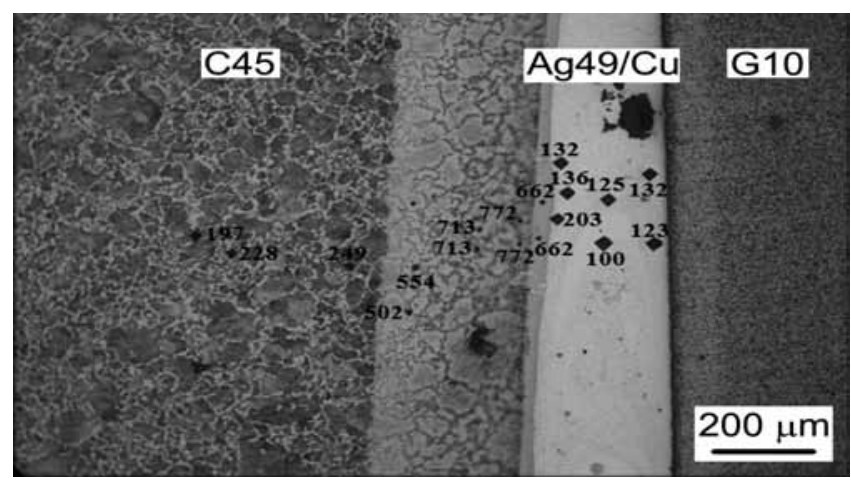

Rys. 10. Rozkład twardości HV 0,1 w połączeniu węglików spiekanych $\mathrm{G} 10$ ze stalą C45 z przekładką Ag49/Cu

Fig. 10. HV0.1 hardness distribution in a joint of hardmetal G10 with steel C45 made with use of an Ag49/Cu spacer granicy stopiwa występuje wąska strefa o strukturze iglastej, wskazująca na utworzenie się struktury Widmanstättena. Następnie widoczna jest struktura perli-

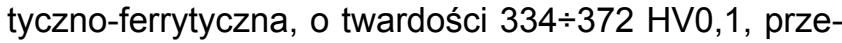
chodząca w strukturę ferrytyczno-perlityczną materiału rodzimego o twardości $203 \div 209$ HV0,1. Rozkład twardości w złączu z przekładką niklową pokazano na rysunku 12.
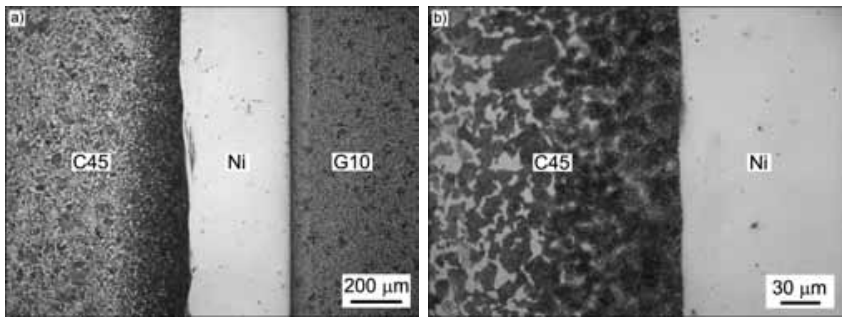

Rys. 11. Mikrostruktura połączenia węglików spiekanych G10 ze stalą C45 wykonanego z przekładką niklową (a), połączenie od strony stali (b), trawione Nitalem

Fig. 11. Microstructure of a joint of hardmetal G10 with steel C45 made with use of a nickel spacer (a), joint on the steel side (b); etched with Nital

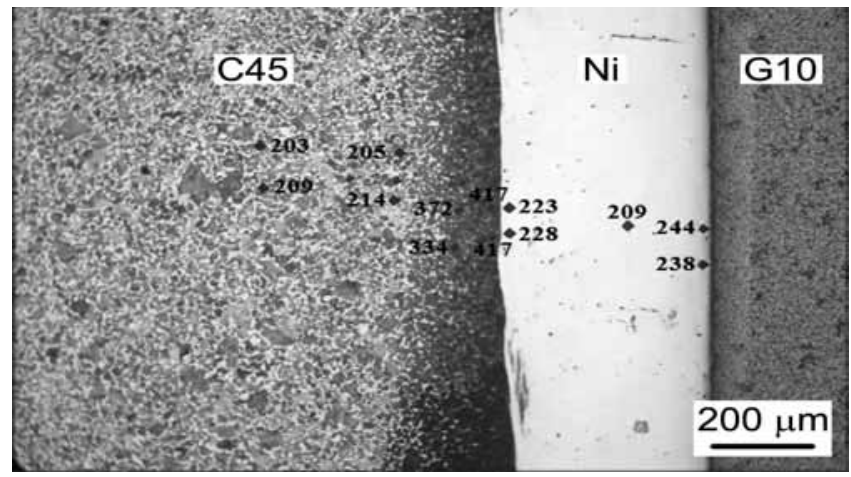

Rys. 12. Rozkład twardości HV0,1 w połączeniu węglików spiekanych $\mathrm{G} 10$ ze stalą C45, wykonanym z przekładką niklową

Fig. 12. HV0,1 hardness distribution in a joint of hardmetal G10 with steel C45 made with use of a nickel spacer

\section{Wnioski}

Na postawie analizy wyników przeprowadzonych badań można sformułować następujące wnioski:

- elementy z węglików spiekanych i stali, przeznaczone do spajania promieniem lasera, wymagają dokładnego przygotowania pod względem wymiarowym i sposobu przygotowania powierzchni;

- możliwe jest bezpośrednie połączenie węglików spiekanych ze stalą przez skierowanie promienia lasera na stal tak, aby nie było bezpośredniego oddziaływania skoncentrowanej energii na strukturę węglików spiekanych;

- wskazane jest zastosowanie przekładek kompensacyjnych między łączonymi elementami z węglików spiekanych i stali. Najlepsze wyniki osiągnięto za pomocą przekładki niklowej w postaci taśmy o grubości $0,1 \mathrm{~mm}$;
- badane połączenia nie wykazały obecności pęknięć, mimo dużych wartości twardości w spoinie i w strefie wpływu ciepła w stali. Wynika to ze stosunkowo małej powierzchni łączenia, nieprzekraczającej $16 \mathrm{~mm}^{2}$, i małej długości połączenia wynoszącej $8 \mathrm{~mm}$;

- połączenia elementów węglikowych ze stalowymi, wykonane za pomocą promienia lasera, sięgały głębokości wtopienia dochodzącej do $3,5 \mathrm{~mm}$. Wydaje się, że znacznie większe możliwości w tym zakresie wykazują techniki lutowania twardego i klejenia;

- wskazane są dalsze próby spajania węglików spiekanych ze stalą promieniem lasera, przez optymalizację parametrów spajania, odległości usytuowania promienia lasera względem elementów węglikowych oraz doboru grubości przekładek kompensacyjnych. 


\section{Literatura}

[1] Mirski Z.: Spajanie węglików spiekanych ze stalą, Oficyna Wydawnicza Politechniki Wrocławskiej, Wrocław 2011.

[2] Nowacki J., Chudziński M., Zmitrowicz P.: Lutowanie w budowie maszyn, WNT, Warszawa 2007.

[3] Pilarczyk J.: Poradnik Inżyniera Spawalnika, tom II, WNT, Warszawa 2005.

[4] Mahler W., Zimmermann K. F.: Löten von Hartmetallen, Schriftenreihe der Degussa, Technik die verbindet, Berichte aus Forschung und Praxis, zeszyt 30, Hanau, 1985, s. 235-240.

[5] Tumanov V. I.: Svojstva splavov systemy karbid volframa -kobalt, Izd. Metallurgija, Moskva 1971.

[6] Mirski Z., Piwowarczyk T.: Klejenie węglików spiekanych i stali w aspekcie zastosowań w przemyśle narzędziowym, VIII Konferencja Naukowo-Techniczna, Problemy i Innowacje w remontach energetycznych PIRE 2005, Szklarska Poręba, 16-18 listopad 2005, Wyd. Ośrodek Badawczo-Rozwojowy Gospodarki Remontowej Energetyki, Wrocław 2005.

[7] Czechowski K.: Klejenie jako skuteczna technika łączenia części skrawających z korpusami narzędzi, 4. Międzynarodowa
Konferencja Naukowo-Techniczna pt. System Projektowania Procesów i Wyposażenia Technologicznego, 5-6 października 2004, Wyd. Politechnika Krakowska, Kraków 2004, s. 49-56.

[8] Czechowski K., Kurleto A., Poselska-Filip I., Wszołek J.: Klejenie części roboczych narzędzi jako technologia alternatywna dla lutowania, Przegląd Spawalnictwa, nr 9/2007, -s. $142-145$.

[9] Żak E.: Sposób zmechanizowanego wykonania połączenia spawalniczego pomiędzy kształtką z węglików spiekanych a korpusem noża do kombajnu węglowego, Patent PRL nr 99949, 30 grudnia 1978.

[10] Żak E.: Sposób przyspawania kształtki z węglików spiekanych do stalowego korpusu narzędzia, Patent PRL, nr 108299, 16 marca 1981.

[11] Żak E., Faruga L., Sołtysek K., Fels M.: Sposób łączenia kształtki z węglików spiekanych z korpusami górniczych narzędzi urabiających, Patent PRL, nr 95334, 25 kwietnia 1976.

[12] Lison R.: Wege zum Stoffschluss über Schweiss- und Lötprozesse, Fachbuchreihe Schweisstechnik, Bd. 131, DVS Verlag, Düsseldorf 1998.

\section{Krajowa Naukowo-Techniczna Konferencja Spawalnicza \\ NOWE KIERUNKI W PROCESACH SPAJANIA I CIĘCIA METALI \\ Poznań, 12 - 14 październik 2011}

\section{SESJA VI}

\section{Piątek, 14.10.2011}

$09^{00}$ - $09^{20}$ Opracowanie metod wprowadzania nanorurek węglowych do jeziorka ciekłego metalu - dr inż. Tomasz Kik, dr hab. inż. Andrzej Gruszczyk - Prof. PŚl, mgr inż. Marek Burda, Politechnika Śląska, Gliwice

$09^{20}$ - $09^{40}$ Ocena wydajności spawania niskoenergetycznego procesu SpeedRoot w pozycji PG - dr inż. Marek Węglowski, RYWAL -RHC, dr inż. Tomasz Chmielewski, Politechnika Warszawska, dr inż. Krzysztof Kudła, Politechnika Częstochowska

$09^{40}$ - $10^{00}$ Podgrzewanie wstępne stali drobnoziarnistych różnymi gazami palnymi i ich wpływ na właściwości materiału - mgr inż. $09^{40}-10^{00}$ Grzegorz Olejnik, Linde Gaz Polska

$10^{00}-10^{20}$ SAT TM wysokowydajny proces MIG MAG do systemów zrobotyzowanych - ESAB

$10^{20}-10^{40}$ Kawa

\section{SESJA VII}

\begin{tabular}{|c|l|}
\hline $10^{40}-11^{00}$ & Mikrostruktura i właściwości eksploatacyjne Inconelu 625 w postaci warstw natryskiwanych cieplnie - dr inż. Artur Wypych \\
\hline $11^{00}-11^{20}$ & Technologia zgrzewania inwertorowego z możliwością rejestracji parametrów w systemie ETHERNET - mgr inż. Mariusz Nowicki \\
\hline $11^{20}-11^{40}$ & $\begin{array}{l}\text { Production Monitoring 2 - zaawansowany system monitoringu produkcji oraz pomiaru energii liniowej przy użyciu techno- } \\
\text { logii True Energy - Lincoln Electric }\end{array}$ \\
\hline $11^{40}-12^{20}$ & Podsumowanie konferencji \\
\hline $13^{00}$ & Obiad pożegnalny \\
\hline 1 & $\begin{array}{l}\text { Pomiarnaprężeń własnych powłok metalicznych natryskiwanych termicznie - dr inż. Tomasz Chmielewski, dr hab. inż. Dariusz } \\
\text { Golański, dr inż. Grzegorz Gontarz, Politechnika Warszawska }\end{array}$ \\
\hline 2 & $\begin{array}{l}\text { Natryskiwanie płomieniowe powłok ogniotrwałych - dr inż. Artur Czupryński, dr inż. Jacek Górka, dr inż. Tomasz Kik, mgr inż. } \\
\text { Andrzej Ozgowicz, Politechnika Śląska, Gliwice }\end{array}$ \\
\hline
\end{tabular}

